chemist's bill I am quite willing provided there is no substitution. I am, Sirs, yours faithfully, Y. M. JONES-HUMPHREXS.

Cemmaes, Montgomeryshire, June 13th 1904.

\section{THE SO-CALLED PANCREATIC REACTION IN THE URINE.}

To the Editors of THE LANOET.

SIRS, - The contention of your correspondents, Dr. C. E. Ham and Dr. J. B. Oleland, that the pancreatic reaction is due to lead salts is at once disposed of by the fact that other acids and neutralising agents than hydrochloric acid and lead carbonate give precisely similar results to those I have described as being obtainable with these reagents. The operations are somewhat more tedious and require considerably more care, but using, for instance, half a cubic centimetre of sulphuric acid to the ten cubic centimetres of urine and, after boiling for five to ten minutes, neutralising with barium carbonate I obtained in over 50 consecutive cases typical crystals with pancreatic urines and no reaction with normal cases.

The pancreatic crystals are undoubted osazone crystals, as their melting points and other characters show, but I am not aware that I have ever stated that they are almost identical with phenylglucosazone - in fact, I pointed out at my lecture that they more closely resembled phenylmaltosazone in most instances. The method of remoring lead from the solution by means of ammonium sulphide, with subsequent heating, adopted by Dr. Ham and Dr. Cleland introduces new factors into the operation which are calculated to interfere with the succeeding stages of the "A" reaction. It is to these that their failure to obtain crystals in the six pancreatic cases they have examined is no doubt due and not to the absence of lead, which, as $I$ have pointed uat above, does not influence the result one way or the other. The clinical diagnosis of diseases of the pancreas has not been my share of the work, but I have every confidence in the surgeons who supplied me with material for $m y$ investigations. The presence of cysts, pancreatic calculi, and gross obstructions of the common duct in a considerable proportion of the cases examined is sufficient to establish the clinical value of the test, which is at present all I seek to maintain.

Dr. F. G. Bushnell's detailed account of the case in which he had the opportunity of examining the urine during life and the organs after death, is interesting further evidence in favour of the diagnostic value of the reaction and an important contribution to our knowledge of the anatomical changes associated with the particular variety of the test he obtained. Crystals dissolving in one to two minutes by both the "A" and the "B" methods are quite what one would have expected with a pancreas showing much interlobular fibrosis (i.e., damage due to past chronic pancreatitis) and a history pointing to long-standing disease of that organ.

The stage of the inflammatory reaction appears to influence the result of the test and it is possible to gauge roughly the progress of the changes in the pancreas by the difference in the amount of the deposit yielded by the "A " and the " $B$ " methods. The short yellow crystals occasionally met with in the control phenylhydrazin test are, in some cases at least, due to traces of a form of maltose but that this is always so I am not prepared to say.

I am, Sirs, yours faithfully,

Beaumont-street, W., June 13th, 1904. P. J. CAMMIDGE.

\section{THE POWERS OF THE GENERAL MEDICAL COUNCIL.}

To the Editors of THE LANCET.

SIRS,-Many of your readers may not have realised the importance of the recent decision of the General Medical Conncil to apply to Parliament for power to compel the names of all students of medicine to be entered on a register under its control. Such a power would be very far-reaching, since it must carry with it the right to refuse registration to the student of any university or licensing body which would not be prepared to modify its requirements in the precise way which the Council might choose to demand. The great services rendered by the Council are recognised by all members of the profession, but there can be little doubt that its present legal powers, taken together with the moral weight which it derives from the individual eminence of its members, are amply sufficient to effect the ends it has in view.
Already the Council claims to be possessed of such rights as the following : 1 . The right to inspect any examination which forms a necessary part of the medical curriculum, including even the earlier examinations in literary and scientific subjects, and to require such changes in scope and method as they think fit, including even the adoption of a particular system of marking. 2. The power to require examining bodies to demand from a candidate before admitting him to examination evidence that he has gone through a particular course of study, lasting for a particular period of time, conducted in particular institutions approved by the Council, and taken at a particular stage in his career.

Attempts have been made by the Council to exercise each of the above-mentioned powers and it is apparently only the fact that its claim to possess them depends upon a doubtful interpretation of the Medical Acts of 1858 and 1886 which has hitherto prevented their enforcement. There is a widespread conviction among many of those concerned with medical education that, if these autocratic requirements indicate the spirit in which the Council conceives it to be its duty to act, any further increase of its power would be eminently undesirable.

I am, Sirs, yours faithfully,

Pembroke College, Oxford, June 13th, 1904.

$$
\text { W. RAM }
$$

\section{THORNE DEFENCE FUND.}

\section{To the Editors of The LaNOET.}

SiRs, - Every medical man engaged in surgical work must feel sympathy with Dr. Mary Thorne in the recent action which she has been called upon to defend and which resulted in an unfarourable verdict against her. Although the expenses of Dr. Thorne's defence were defrayed by the Medical Defence Union, of which she is a member, she is herself responsible for the damages awarded against her and also for the plaintiff's costs which together amount to about $£ 250$. It has therefore been decided to raise a fund to assist Dr. Thorne in meeting this expense and as a means of showing the practical sympathy of the medical profession with her. We are, Sirs, yours faithfully,

WALter S. A. GRIFFith.

WALTER TATE.

DOUgLas DREW.

PS.-Dr. Tate, of 32, Queen Anne-street, London, W., will be pleased to receive and to acknowledge any subscriptions to the fund. The following is the first list of subscribers :-

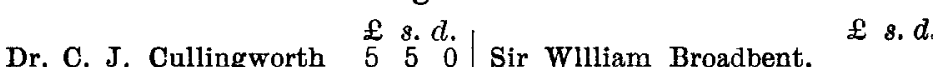

Dr. Walter S. A. Griffith Dr. Walter $\mathbf{W} . \mathbf{H}$. Tate. Mrs. E. Garrett Anderson, M.D. Mrs.

Mrs. Stanlë Boyd, $\dddot{M} . \ddot{D}$ Dr. Herbert R. Spencer Mr. Douglas Drew Mr. J. Berry Mr. J. Berry $\ldots$. $\ldots \ldots$ Berry, M.D.

M. Routh Mr. Stanley Boyd ... ...

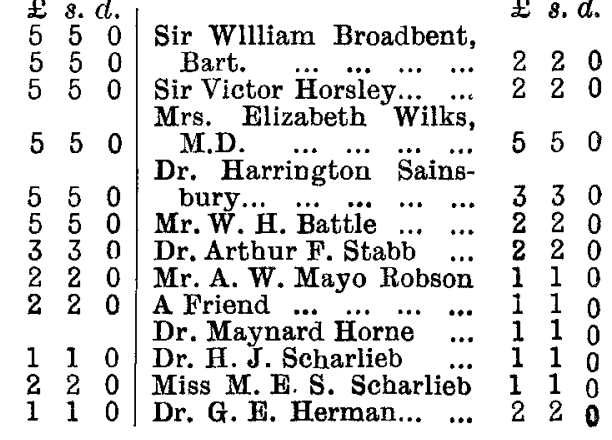

\section{ABSCESS OF THE FRONTAL SINUS. To the Editors of THE LANOET.}

SIRS, - I am surprised to see that Dr. R. S. Wainewright in his letter to THE LANCET of Jane 11th, p. 1687, referring to the external swelling caused by perforation of a frontal sinus empyema, says that he cannot find it mentioned in any book. The reason why this swelling is not accorded a prominent place as a symptom by nasal specialists is that they generally diagnose empyema of the frontal sinus at a stage considerably earlier than that of external swelling and cases accom. panied by swelling usually come into the hands of the ophthalmic or the general surgeon. In spite of this, among the books I happen to have within reach this condition is referred to in "Diseases of the Upper Respiratory Tract," by Watson Williams, fourth edition, pp. 379 and 380 ; "Manual of Surgical Treatment," by Oheyne and Burghard (Lambert Lack's article), part v., p. 339; Heath's "Dictionary of Practical Surgery," and Sheild's article in Treves's "System of Surgery," vol. ii., p. 348. A very complete account of its causation, position, 
and appearance, with an illustration, may be found in Hajek's work on the "Inflammatory Diseases of the Accessory Sinuses of the Nose," pp. 135 and 145. After reading these descriptions I trust that Dr. Wainewright will no longer assert that "even the greatest nasal specialists seem still to be entirely ignorant as to its nature." I may point out that a clear distinction should be made between the swelling due to expansion of the bone by the rare muco. cele and that caused by an abscess after perforation of an empyema wbich ha dly ever expands the bone.

Dr. Wainewright turther says of these cases that "all that is necessary to do is to make an incision through the swelling and pass a drainage-tube into the cavity of the nose." Now this is by no means so simple as it sounds; the opening into the nose is normally much too small to admit a drainag $\dot{\epsilon}-\lrcorner$ ube and is always much narrowed in those cases which go on to perforation; further, the perforation is usually too small to work through and must be enlarged. These cases are severe and there are often present areas of caries and polypoid degeneration as well as associated disease of the ethmoidal cells, all of which must be treated if a cure is hoped for. It is a pity that such simple methods as Dr. Wainewright mentions are not usually sufficient but experience shows that they seldom are. The question of complete obliteration of the cavity is too long to discuss here, but there is much to be said in favour of this procedure in certain advanced cases. At least, we cannot dismiss it as shortly as Dr. Wainewright does from among our means of treating a class of case often exceedingly difficult to bring to a complete and final cure.

I am, Sirs, yours faithfully,

Wimpole street, June 14th, 1904.

HAROLD BARWELL.

\section{COUNTING MATTRESS SPONGES IN ABDOMINAL OPERATIONS.}

\section{To the Editcrs of THE LANCET.}

SIRS,-A simple method of preventing mattress sponges being left behind in abdominal operations is to have a piece of tape sewn to one corner of the sponge. The tape should be about a foot long so that when the sponge is introduced into the abdomen the tape hangs outside over the edge of the wound on the abdominal wall. To keep it taut a leaden bead or button may be strung on to the end of the tape and secured by a knot. The beads or buttons-the button being flat is the better of the twc-can be readily sterilised and, of course, used again and again. As there is a tape ontside for every sponge inside all that it is necessary to do before the wound is stitched ap is to count the tapes, to find if they tally, and then to draw out the sponges by pulling each tape separately. The method, I think, is used in Dublin. I am, Sirs, yours faithfully,

June 11th, 1904. J. JOHNSTON ABRAHAM.

\section{SPLENIC AN ÆMIA.}

\section{To the Editors of THE LANOET.}

SIRS,-The following case of mine suggests whether it is not the removal of the spleen (as stated by Dr. F. Taylor in the Lamleian lectures) which relieves in splenic anæmia but the excessive loss of blood which takes place in such an operation, and whether bleeding to an extreme degree is not indicated as a method of treatment in splenic anæmia both to give an impetus to the blood-forming organs and to get rid of a poison inhibiting the action of those organs. $A$ tin miner aged about 30 years, consulted me for extreme anæmia with enlarged spleen. No blood count was made. He failed to improve under iron and increasing doses of arsenic until he had a violent attack of epistaxis which nearly cost him his life, after which with the same treatment he completely recovered to all appearances, regained his colour, and went to America to mine where he was well and working three years afterwards. I cannot remember the after state of the spleen definitely.

I am, Sirs, yours faithfully,

Camborne, Cornwall, June 11th, 1904. JoHN H. TONKING.

\section{RESPECT FOR DRUGS.}

\section{To the Editors of THE LANCET.}

SIRS,-My attention has been called to the review of my work on "Drugs" which appeared in THE LANCET of
May 14th, p. 1358. Whilst thanking you for the space you have given to a notice of my book and your reviewer for pointing out several slips which have evaded the vigilance of the proof-readers I cannot but think that your contributor is hypercritical in some of his comments. He objects to the statement that "all drugs are poisons," not that he disputes its truth bat because be fears it may be used to throw doubt on the value of medical science. Is it not equally probable that it may help to hinder the habit of self-drugging which is so fatally fashionable? Personally I have always found it essential to impress students with a proper respect for the drugs they handle. Your reviewer does not like the system of classification I have adopted. It has its drawbacks undoubtedly, in common with every other known system, but as students have to recognise specimens it would seem well that they should consider those that are alike in external characters together-e.g., leaves with leaves and roots with roots.

May I hope that the comparative triviality of the errors and misprints which your contributor has noted indicates the absence of serious faults?

June 10th, 1904. I am, Sirs, yours faithfully,

\section{TAPEWORM IN A CHILD.}

To the Editors of THE LANCET.

SiRs,-Apropos of Dr. J. A. Rigby's case of tapeworm in a child, aged 34 months, published in THE LANCE $r$ of May 14th, p. 1348, I beg to enclose a reprint of a report of a somewhat similar case in a child, aged 24 months, observed by me some three years ago.

The case was reported to the Philadelphia Pediatric Society not only as an instance of infection at a very tender age but principally to point out the danger of giving raw beef to young children-a custom quite prevalent at present in the United States and for which L. Emmet Holt is largely responsible. A tapeworm is not a desirable guest for a young child to entertain; indeed, its presence is not altogether devoid of danger, while its removal is often a matter of extreme difficulty. For this reason it would seem to be the part of wisdom to reserve the use of raw beef for those extreme cases of dyspepsia in which the proteids of cow's milk, however altered or modified, are digested with great difficulty and for the treatment of certain cases of chronic diarrhoea.

I am, Sirs, yours faithfully,

Philadelphia, U.S.A., June 1st, 1904.

D. J. M. MILleR.

\section{THE IMPURE AIR OF CHURCHES. To the Editors of THE LANOET.}

SIRs,-During the last two years I have visited during service more than 100 churches in the South of England, both in towns and country. In these days when "open-air treatment" and the merits of the open window are preached it is remarkable how the churches fail to keep pace with the times and keep their windows rigorously shut. Many country churches have no windows that will open or other means of ventilation; in others the very small and few windows made to open are kept closed. The churches in so-called health resorts are the worst offenders. They have large congregations, many services, and little ventilation. In winter artificial heating by hot-water pipes is common, and in the evening the lighting is by gas or oil lamps, and occasionally by electric light. The air at the end of a crowded service is foul beyond description. Not 5 per cent. of the churches which I bave seen have any proper ventilation except the newer ones which have apertures or windows high up near the roof and other windows not hermetically closed. In the vast majority week after week the foul and stagnant air is never renewed; the dust and numerous germs, pathological and otherwise, remain year after year in the crevices of antique wood or stone work. One sees occasionally sufferers with the streaming eyes and nose of cold or influenza; one hears the cough of phthisis or pertussis. The writer has known several cases of illness directly due to visits to these malodorous and unwholesome services and many of my medical brethren could confirm this. Of course the subject is a delicate one. Some of my clerical friends readily admit the bad air of the churches but hesitate to oppose the ignorant prejudices of many worshippers and their pious horror of so-called draughts. Those I visited belonged to the Church of England. Those of other sects, so far as I can learn, 